\title{
Kate Chopin's The Awakening: A Postmodernist Study
}

\author{
Nazmi Al-Shalabi \\ The Hashemite University, Jordan
}

Doi:10.5901/mjss.2015.v6n5s2p276

\begin{abstract}
It is argued that Chopin's The Awakening is a realistic novel, that it is a feminist novel, and that it is a naturalistic novel. This study is based on the assumption that Chopin's novel is postmodern. The method used is analysis. This analysis focuses on Edna's character as well as the other characters that are ordinary humans. It also deals with Edna's life, and shows that it is meaningless .Furthermore, this analysis demonstrates that the Pontlliers family is collapsing, that Chopin uses irony, that she makes use of other traditions, such as realism, romanticism, and naturalism, that the narrative style of the novel is simple, and that the end of the novel is open to interpretations. Generally speaking ,this comprehensive analysis shows that Chopin's novel is postmodern despite its date of publication. It has been demonstrated that Chopin's novel is postmodern on account of its simple narrative style, its theme that centers on Edna's independence which is an inner problem, and its characters that are life-like. This novel is also marked by irony, self-reflexivity, intertextuality, and being open-ended, which are all characteristics of postmodernism.
\end{abstract}

Keywords: Postmodern; reaction ; hallmark ; self-reflexivity; intertextuality; absurdity

\section{Introduction}

Chopin's The Awakening, the focus of this paper, has been viewed differently by scholars. To take an example, George Arms, in "Kate Chopin's The Awakening in the perspective of her Literary Career," claims that The Awakening is seen in terms of the question of sexual freedom (216). Joan Zlotnick(1968), similarly, contends that the novel can be also read as a strongly feminist novel. Like G. Arms and Zlotnick, Edmund Wilson(1966) sees the novel as " an anticipation of D.H. Lawrence in its treatment of infidelity"(590).In a similar manner, Kenneth Eble (1964) maintains that " the novel is an American Madame Bovary ,though such a designation is not precisely accurate. Its central character is similar: the married woman who seeks love outside a stuffy, middle-class marriage"(vii-viii).

Like Eble, Per Seyersted claims, in Kate Chopin: A Critical Biography, that The Awakening focuses on the theme of "female self-assertion."(160-161). This theme is at the center of Edna's attention. Edna, the central character, is so infatuated with her independence that she abandons her husband and children to be free. This behavior shows that she gives priority to her independence over her love for her children and husband. By abandoning her family, Edna runs counter to her audiences' expectations. She is expected to mother her husband and children, not abandon them. In short, Edna's behavior is not motherly. In her capacity as a mother and wife, she is expected to make sacrifices. Judged by its setting, characters, and plot, The Awakening can be also read as a realistic novel. The characters are life-like; the place where the action occurs is familiar to audiences. The happenings are also realistic. The love affair between Edna and Robert is a daily occurrence. Edna herself is both realistic and romantic. She rejects the status quo, and determines to be independent.

Besides being a realistic and feminist novel, The Awakening can be also interpreted as a naturalistic novel. In this case, Edna becomes a victim of her environment, of the social forces that shape her own identity. To these readings of the novel I want to add up my present one that it is a postmodern novel. To do this job, I want to analyze this novel within a postmodern frame.

\section{Literature Review}

A number of studies have been done on Chopin's The Awakening. In 1971, Jules Chametzky wrote a paper that was read before the German American Studies Association in Heidelberg. This paper is titled Our Decentralized Literature: A Consideration of Regional, Ethnic, Racial, and Sexual Factors.

Wondering, Chametzky argues:"What does surprise one is the modernity ... of Chopin's insights into 'the woman question.' It is not so much that she advocates woman's libidinal freedom or celebrates the force of the body's 
prerogatives... What Kate Chopin shows so beautifully are the pressures working against woman's true awakening to her condition, and what the condition is "(1).In another study titled Chopin's The Awakening: A Critical Reception, it is claimed that critics have condemned Chopin's novel, regarding it to be "vulgar, unwholesome, unholy, a misappropriation of Chopin's exceptional literary talent"(Sprinkle,1998). In a third study titled Kate Chopin's The Awakening : Struggle against Society and Nature, it is argued that Edna is fighting against "the societal and natural structures of motherhood that force her to be defined by her title as wife of Leonce Pontellier and mother of Raoul and Etienne Pontellier, instead of being her own , self-defined individual"(Kaplon,2012). Megan Kaplon goes on to say that Edna attempts to find self-definition " by creating a third lifestyle option and beginning to act like a man"(1). In a fourth study titled The Masculine Sea and the Impossibility of Awakening in Chopin's The Awakening, it is claimed that the male socio-cultural formation does not let women experience freedom(Abbasi,2012). Abbasi regards the sea to be a signifier of the male society. As long as Edna drowns at sea, Abbasi argues that the sea leaves no room for women's true existence. This review of literature shows that the studies done on the novel focus either on Edna or on Edna's relationship with the society. It also suggests that treating Edna as a human not possession is the best solution for her problem. Moreover, this review makes it clear that the only way to stop Edna and the like from having affairs with other men and committing suicide is to raise the consciousness of husbands, and convince them of the necessity of shouldering their responsibilities toward their wives whom they should harbor love for, respect, and treat as humans. These husbands should also reckon with the right of children to live with parents who love them, look after them , and make sacrifices for them.

\section{The Significance of the Study}

This study contributes to literature as it demonstrates that The Awakening is a postmodern novel despite its early date of publication in 1899.Chopin's treatment of the theme of women's independence makes her a forerunner. She is a feminist who demands more rights for women. She draws people's attention to the restrictions that marriage imposes on women. She seems to be saying that marriage divests women of their independence and keeps them oppressed by men.This oppression is "the most important political factor in women's lives" (Ashcroft,1998).Chopin's treatment of this theme is significant because it makes her novel a feminist classic at an early date.

\section{Methodology of the Study}

The method used in this study is an in-depth analysis of Edna's character and life, Chopin's narrative style, novel structure, theme, and setting. This analysis is a prerequisite for demonstrating the characteristics of postmodernism that characterize The Awakening.

\section{Objectives of the Study}

The main objective of this study is to show that Chopin's The Awakening is a postmodern novel .In spite of the fact that the novel was published in 1899, a careful examination of the central character's problem shows that it is an inner problem, which is a postmodern characteristic. By extending the examination to Edna's life, it becomes clear that Edna's life is meaningless, which is also another characteristic of postmodernism. A similar examination of the Pontelliers reveals that their family is disintegrating, and that they are ordinary humans, which constitutes two markers of postmodernism. Parallel examinations of the narrative style that is simple, of the setting that is not fixed, and of the multiple traditions Chopin makes use of ,such as realism, romanticism, naturalism, and local color writing reveal that the novel is postmodern.

\section{Roots of Postmodernism}

The term postmodernism has been the subject of heated debates. It was first coined, Nicol contends, in the 1940s to describe a reaction against modernism in architecture. As regards its use, Nicol adds, it began to be widely used in the 1960s by American cultural critics and commentators, especially Susan Sontag and Leslie Fiedler who wanted to describe a new trend in literature that either rejected modernist techniques or adapted or extended them. In the following decades, the term postmodernism began to figure in academic disciplines besides literary criticism and architecture - such as social theory, cultural and media studies, visual arts, philosophy, and history(p.1).Like Sontag and Fiedler, Ihab Hassan , an American critic, used this term to specify certain tendencies in literature in the 1960s.To 
take an example, in The Dismemberment of Orpheus : Toward a Postmodern Literature, Hassan(1982) argues that "the postmodern spirit ... is not really a matter of chronology "(39). Regarding the relationship between postmodernism and literary criticism, he claims that the postmodern is not simply a major cultural shift; it also involves a new relationship between humans and the milieu.

\section{Postmodernism: A Literary Trend}

As a literary trend, postmodernism succeeds modernism. It is, Hooti (2011) claims, "a dramatic deviation of man's thought line; it is a renaissance towards breaking the fossilized shackles of the prescribed norms and notions, which have changed into economic and political institutions" (40). Hooti adds that postmodernism is "...a new era of endeavor whose activities are unclear and whose meanings and implications are not yet well understood"(41). Like Hooti, Waugh(1984) comments on literary postmodernism claiming that it is a "quest for fictionality" (10), one that is oriented towards uncertainty. In a post-modernist fiction, everything exists, Lewis (2001) maintains, "in such a radical state of distortion and aberration that there is no way of determining from which conditions in the real world they have been derived or from what standard of sanity they may be said to depart" (123). Commenting on the characteristics of this type of fiction, Lewis adds that the "conventions of verisimilitude and sanity [are nullified] "and that "characters inhabit a dimension of structureless being in which their behavior becomes inexplicably arbitrary and unjudgeable because the fiction itself stands as a metaphor of a derangement that is seemingly without provocation and beyond measurement" (123). Lewis is saying that the postmodern novel does not hold up a mirror to reality, and that it is not a copy of the external world. Arguing in support of this contention, Waugh (1984) holds that postmodern fiction can" never imitate or 'represent' the world but always imitates or "represents" the discourses which in turn construct that world"(100).

Emphasizing the fictional world of postmodern fiction, Lodge (1992) holds that postmodern Novel is "fiction about fiction: novels and stories that call attention to their fictional status and their own compositional procedures" (206). Shedding further light on the postmodern fiction, Alridge(1983) contends, in The American Novel and the Way We Live Now, that in the fiction of postmodernist writers "virtually everything and everyone exists in such a radical state of distortion and aberration that there is no way of determining from which conditions in the real world they have been derived or from what standard of sanity they may be said to depart. The conventions of verisimilitude and sanity have been nullified. Characters inhabit a dimension of structureless being in which their behavior becomes inexplicably arbitrary and unjudgeable because the fiction itself stands as a metaphor of a derangement that is seemingly without provocation and beyond measurement" (qtd. in Lewis:123). The reason underlying postmodernists' attitude towards the external world is that they believe that there is no reality to be reflected, no absolute truth, and that the universe itself has no center. For these reasons, meaning and coherence, to them, do not exist in the world or the text. This stand renders postmodernists closer to the advocates of post-structural theory of literature who refuse to accept, Norris (1982) argues, "the natural link that common sense assumes to exist between word and thing "(4). Poststructuralists believe that signifiers have no definite signifieds, and that signifieds are legion, which is conducive to a multiplicity of meanings which cannot be grasped because there is no fixed intellectual reference in the world where we live. This multiplicity of meanings connected with the myriad signifieds can be equated with indeterminacy which is a marker of any postmodern novel.

\section{Analysis of The Awakening}

In this study, I hold that Kate Chopin's The Awakening is a postmodern novel for a number of reasons. Firstly, the focus of the novel is Edna's independence which is an inner problem. Edna is determined to be independent, regardless of her roles as both a wife and mother. Maddened by her hunger for being herself and independent, she determines to abandon her husband and children, which is a sign of her rejecting mothering, trampling on the beliefs and norms of the West. It is worth noting that the rejection of the Western beliefs and values represents an important characteristic of postmodernism. In stark contrast with postmodernism, modernism attaches a great value to the ideas, beliefs, norms and culture of the West.

Secondly, The Awakening is postmodern because the characters in it are ordinary men and women. These characters are either middle or low class people. They are unlike the classical works characters who are rulers, princes, princesses, and nobles. Chopin's characters are hollow, which is probably meant to reflect the absurdity of their lives and culture. This absurdity itself is a characteristic of postmodernism, and characterizes Edna's life that is meaningless as long as she is not independent. To change her life into a meaningful one she decides to abandon her family. This choice provides the indication that she is frustrated and fed up with marriage that deprives her of the chance of being herself, 
clearly demonstrates that independence and self-assertion are both superior to love, and hints at her society that is a patriarchy. In this society Edna realizes that she won't be able to enjoy autonomy and independence. This realization occurs despite her choice to abandon her husband and children who badly need her. Edna's decision to do so means that she has chosen to be alone. As long as she lives in a male-dominated society, she won't be as free as she wants. Rather, she'll be subordinated to males, and she'll be lacking both voice and place.

As far as place is concerned, the notion of place in The Awakening comprises the third reason for its being a postmodern novel. Like other postmodern works, "place" in this novel is not fixed. It changes and traps people inside. During her awakening that is a staple theme Edna stays in many houses. She stays on Grand Isle, Madame Antoine's home, the big house in New Orleans, and her "pigeon house." Each one of these houses demonstrates her progress while awakening. On Grand Isle, for instance, Edna discovers that she is capable of doing a couple of jobs at least. The first job is that she meets Robert Lebrun through whom she realizes that her husband is a "person whom she [has] married without love as an excuse" (147). The second job is that she walks with Robert on the beach without worrying about people's gossips. In stark contrast with this image of Grand Isle is that this place itself traps her because it is surrounded by water and is separated from the mainland. This place traps her the same way society does. Just as water surrounds this place and restricts her freedom so does the society in which people are unready yet to accept her. To flee being trapped, Edna determines to leave Grand Isle for New Orleans. Commenting on this, Chopin's narrator holds: "As their stay at Grand Isle drew to its close, she felt that she could not give too much time to a diversion which afforded her only real pleasurable moments that she knew" (87).The mansion in New Orleans acts the same way the house on Grand Isle does. Its walls keep her imprisoned. Telling Mademoiselle Reisz about this mansion, Edna claims that she is "tired looking after that big house. It never seemed like mine, anyway - like home" (151). Afterwards, Edna moves to the "pigeon house" (87), her new residence. The pigeon, Black observes, is a "domestic bird, usually monogamous, that we associate with a coop or wobbling parasitically on the ground, hoping to be fed" (105). When the awakened protagonist "nests in the little house," Black adds, the reader won't be convinced that Edna "will have the strength to soar and fly away" (105". Edna's helplessness to fly is stressed in the last chapter's bird that has a broken wing (216-21). In this residence, Edna determines to abandon her duties as a wife and mother. When Adele hears of that, she criticizes her, arguing that she is not doing the right thing. Adele maintains," In some way you seem to act without a certain amount of reflection which is necessary in this life" (91). Refusing to follow Adele's steps, Edna begins to make her choices and to" do as she [likes] and feel as she [likes] "(54). Thus, she becomes confident of herself, believing that she'll "never again ... belong to another than herself" (76). Driven by self-confidence and the obsession with independence, Edna sets off her journey, trampling on societal norms, especially marriage and family. In so doing, she destroys the family whose disintegration is in full vigor in The Awakening, and forms the fourth reason for the contention that it is a postmodern novel. The Pontelliers' marriage that collapses is contrasted with the Ratignolles' which seems to be flawless and a perfect union between two humans whose fusion into one, if ever it "has been accomplished on this sphere, it was surely in their union" (54). The reason underlying this contrast is that Chopin probably wants to demonstrate that it's possible for couples to live happily if women willingly accept their roles as wives and mothers, which means that they conform to Western values, beliefs, ideas, and norms. Adding one more contrast to the preceding one, Chopin contrasts Edna with Adele who is a submissive wife whose happy marriage is meant, Pease contends, to show that "happy marriage was only possible if a woman took over the role of a submissive wife and only answered to her husband's desires" (17). These contrasts are probably intended to insinuate that Edna's refusal to stick to the aforementioned roles gives rise to the tragedy occurring at the end of the novel, although some scholars regard it to be an awakening.

In respect of awakening, Edna awakens not only to who she is, but also to the social confinements and the impossibility of her being completely free in the society. This awakening seems to be akin to Chopin's. While Edna longs for being independent, Chopin herself yearns to "write works that go beyond female plots and feminine endings" (xi). Another point that is worth mentioning is that Chopin and Edna are both defiant. Whereas Chopin defies the literary tradition, Edna, her heroine, defies social conventions that she holds to be confining. These conventions stand in her way of becoming herself. They divest her of her identity, and keep her subordinated to her husband who holds her to be his own property. He looks at her "as one looks at a valuable piece of personal property that has suffered some damage" (635). This husband's relationship with her parallels that existing between a master and his servant. The resemblance between Edna's awakening and Chopin's echoes the resemblance between Chopin and Mademoiselle Reisz. In "Tradition and the Female Talent: The Awakening as a Solitary Book," Elaine Showalter expresses the view of many critics when she claims that Mademoiselle Reisz's "voice in the novel seems to speak for the author's view of art and for the artist" (214). She also adds that Mademoiselle Reisz speaks to "Kate Chopin's ambitions as an artist and to the emotions she wished her book to arouse in its readers" (215). In view of this resemblance between Edna's awakening and Chopin's on the one hand, and between Mademoiselle Reisz and Chopin on the other , it can be said that Chopin's 
novel is postmodern for a fifth reason which is self-reflexivity.

In addition to self-reflexivity, The Awakening is postmodern for a sixth reason connected with its narrative style. This novel is simple and flows smoothly; it is written in a simple language, which makes it easy for readers to read and understand it. Besides simplicity, Chopin's novel employs irony which is a hallmark of postmodernism, and makes it easy for readers to get the writer's message, and know about the theme. An ironic situation can also allow the reader to distinguish between appearance and reality. The type of irony used in the novel is called irony of situation which occurs "when there is", Angela Janovsky argues, "incongruity between what is expected to happen and what actually happens" (Study.com). Audiences don't expect Edna to commit suicide. Hence, the ending of the novel falls short of their expectations. Edna realizes that she lacks real love, that she is unhappy with marriage and motherhood, that she cannot flee sex and childbearing, and that it is futile to find an alternative way of life. It is ironic that this realization occasions her death.

Although death ends the novel, it keeps the door open to interpretations. These interpretations themselves comprise the seventh reason justifying the claim that The Awakening is a postmodern novel. One interpretation is that Edna's death represents an escape from the society that is quite unprepared to accept her. This society's laws won't do her justice; people themselves are still unready to accept her because her new status outstrips their expectations. Another interpretation is that Edna's death is suicide even though Chopin does not explicitly say that. In the last chapter, Chopin depicts her central character as being pleasant and chatty with the people she sees (217). Edna also asks Victor Lebrun for some dinner, especially fish (218), and to set up a place for her to spend the night. Choosing not to wait for dinner, she decides "to go down to the beach and take a good wash and even a little swim, before dinner" (218). Chopin provides nothing indicative of Edna's intention to commit suicide. Edna's situation is sorrowful and pitiful. She is desperate because she has left her husband and children; she has lost her lover; she does not know how to be herself in the context of society. In addition to these reasons, she is unready to go back to her husband and be reunited with him. Reckoning with the reasons given, Edna's choice to commit suicide becomes understood. She wants to be herself, but she cannot conform to social confinements, cannot manipulate sex and childbearing, and cannot be free. To fulfill her dream of independence and freedom, she dies out of despair. A third interpretation of the ending is that Edna's choosing to die does not mean that she is hateful of life. She wants to live, but realizes that nothing can be done about the society and its restrictions. A fourth interpretation is that Edna kills herself this way because of her low self -esteem and worthlessness. A fifth interpretation is that she makes this choice because it's better to die than to lead a life out of her control. Moreover, Edna's suicide can be viewed as an awakening to the relief it provides, the freedom it offers her, and the place she is entitled to. While death enables her to have a place of her own, the society where she has been caged denies her this place. These multiple interpretations of the ending of the novel parallel the multiple literary traditions embraced in the text of the novel, such as realism, naturalism, romanticism, and local color. These literary movements certainly enrich the text and influence the narrative style of the novel. They clearly show that Chopin has chosen not to limit herself to a literary stance, but to make use of them, diminishing each one within the text. Arguing in support of this contention and commenting on Chopin's style of writing, Skaggs(1974) holds, in "Three Tragic Figures in Kate Chopin's The Awakening that four major literary movements can claim some aspect of The Awakening, for in this "small compass... [is illustrated] virtually all the major American intellectual and literary trends of the nineteenth century" (80). Echoing Skaggs, Neil Wyatt(1995) maintains that "[t]he overriding romantic theme in the novel is Edna's search for individuality and freedom: ... This search amounts to her own romantic quest for a holy grail, a grail of self-definition" (1). Other romantic themes are emphasis on nature, the use of color, the memories of childhood, the sea and its sensuous call, the romantic music in the background, and Edna's desire to express herself through art. As regards naturalism, Wyatt adds that "[t]he aspect of naturalism most evident in The Awakening is the portrayal of Edna as a hostage to her biology. She is female, has children, and is a wife in a society that dictates behavioral norms based on those conditions" (1). Another naturalistic element in the novel is "the portrayal of Edna as a victim of fate, chance, of an uncaring world, pulled into a consuming, but indifferent sea. In the end, despite her developments into self-hood, the only escape from biological destiny as a woman in society, possessed, sexual, and ruled, is death"(1).

Regarding realism, it lies in Chopin's appeal to the "heart of a common housewife" that is a married woman who sits alone in her house crying to herself (491). It also lies in the treatment of the sexuality of men and women, the realistic characters, the realistic setting, and the realistic happenings. Chopin chooses a realistic setting and characters that are all life-like. She also explores the emotional depth of these characters, revealing them through their actions and choices, which gives readers the chance to judge them, and determine whether they are right or wrong. This novel itself becomes a local color writing due to Chopin's detailed descriptions of the setting and the people around Edna. 


\section{Chopin and Other Writers}

In addition to these literary traditions, scholars have, for so many years, acknowledged Chopin's familiarity with philosophical works and other writings. To take an example, these scholars refer to the Nietzschean strain in Chopin's writings, especially The Awakening. In the introduction to a new edition of Chopin's first novel At Fault (1890), editors claim that "numerous critics have remarked on Chopin's familiarity with philosophical works, especially the German romanticism of Friedrich Schopenhauer and Friedrich Nietzsche" (Green and Caudle xxi).Similarly, Patricia L. Bradley quotes Martha Fodaski Black's argument, in an essay titled "The Quintessence of Chopinism," that the bird imagery in the opening scene of The Awakening is akin to George Bernard Shaw's using birds in a similar manner in a feminist essay titled "The Womanly Woman."Black also mentions other source texts, such as Mary Wollstonecraft's "A Vindication of the Rights of Women" (1772), George Eliot's Middle March(1872), and Niewtzsche's Beyond Good and Evil (1886). Of these texts, Black picks Skaw's text holding it to be an influence on Chopin because Shaw's views were available to Chopin when she was writing her novel. In support of her argument, Black claims, "evidence of [Chopin's] reading [Shaw] is implicit in The Awakening" (97). Like Black, Arnavon regards The Awakening to be "modeled upon Flaubert's Madame Bovary" (188), and, thus, Chopin's familiarity with Flaubert's novel as well as similarity in theme suggests her intertextuality with Flaubert, who is the focus of another comparative study done by Susan Rosowski. In this study titled "The Novel of Awakening," Susan compares Flaubert and Chopin's novels. In her comparison, Susan contends that Flaubert "maintains ironic distance" from Emma, but Chopin focuses "strictly upon changes of consciousness" within Edna (316). Remarking on Flaubert and Chopin's approaches, Bernard Paris contends that Flaubert ridicules "Emma's romanticism," (198), but Chopin focuses on a "woman's awakening" (215). Following Paris's steps, Thornton claims that Chopin "goes beyond merely imitating Emma and the problems Flaubert imagined for his heroine"(50). I hope I have demonstrated that The Awakening is a postmodern novel. After introducing postmodernism, I have argued that the novel is postmodern for a number of reasons, such as concentrating on Edna's independence that is an inner problem, choosing characters that are middle or low class people, reflecting the absurdity of life, showing families that are in decline, self-reflexivity, using irony, embracing multiple literary traditions, demonstrating intertextuality, and making it clear that "place" is not fixed.

\section{Conclusion}

In this novel, Chopin traces Edna's journey of independence. She blends romanticism, realism, naturalism, and local color writing, weaving them all into a novel that was rejected just because of its sexual content and Edna Pontellier's conduct. Edna tramples on the social mores and conventions, and has affairs outside of marriage, but Chopin does not condemn her at all. Edna goes on with defying the society where she lives, and decides to abandon not only her husband but also her children because the Creole society forbids women to be themselves. In so doing, she runs counter to readers' expectations. These readers look at her actions, and make their own choices. They may or may not sympathize with her. It's all up to them. These readers are also invited to judge her once more when she commits suicide at the end of the novel. Readers who are keeping an eye on Edna's struggle for freedom and independence don't feel at ease when they read about Edna's death. Chopin does not prepare them for this event that ends the novel and keeps it open to interpretations. By leaving the novel open-ended, Chopin offers no decisive solutions. As a postmodern writer, she recommends no ways to recovery. She is just a reflector who calls marriage into question, and her central character's behavior reflects the postmodern condition in which the old grand narratives of Christianity and morality have no longer any place. In the postmodern world, there is no exact meaning for religion and morality. Chopin gives readers the opportunity to approach reality the way they like because postmodernism is an age of uncertainty, in which everything remains unresolved and open-ended. It is true that Chopin depicts ordinary women who are as caged as birds are, who are lacking freedom and independence, who are oppressed, and who are facing the danger of suffocation. Women suffering this way cannot do without freedom and self-assertion. Hence, they quit their roles as wives and mothers to be themselves. Thus, families collapse and the world becomes chaotic. The problem is that Chopin does not condemn these women's deeds, and that she doesn't offer any solution either.

\section{References}

Abbasi , P.(2012). The Masculine Sea and the Impossibility of Awakening in Chopin's The Awakening. kata2012,14(1),1-42,DOI: 10.9744/kata14.1.37-42. http://puslit2.petra.ac.id/ejournal/index.php/ing

Alridge,John.(1983).The American Novel and the Way We Live Now. New York and Oxford University Press: Modern Humanities 
Research Association.

Arms, George.(1967).Kate Chopin's The Awakening in the Perspective of Her Literary Career.Essays on American Literature in Honor of Jay B. Hubbell Durham, N.C. : Clarence Gobdes.

Arnavon, Cyrille(1979). Introduction to Kate Chopin, Edna. Trans. Bjorn Braaten \& Emily Toth. In Per Seyersted and Emily Toth (Eds.), The Kate Chopin Miscellany(pp.168-188).Toth. Natchitoches, L.A.: Northwestern UP.

Ashcroft et al.(1998). Key Concepts in Post-Colonial Studies. London : Routledge.

Black, Martha F.(1992).The Quintessence of Chopinism. Boren and Davis.95- 113.

Bradley, Patricia L. (2005).The Birth of tragedy and the awakening: Influences and intertextualities. Southern Literary Journal, 37, 4061. muse.jhu.edu/journals/sli/summary/v037/37.2bradley.html

Chametzky,Jules(1971).Our Decentralized Literature: A Consideration of Regional, Ethnic, Racial, and Sexual Factors. Paper Read before the German American Studies Association in Heidelberg.

Chopin, Kate.(2003). The Awakening. In Norton Anthology of American Literature(pp.633-722). New York:W. W. Norton.

... (2009). The Awakening. American Literature. Comp. Wilhelm, Glenco

Jeffery. McGraw Hill, Columbus, OH. p. 491.

Eble ,Kenneth(1964).Introduction to The Awakening .New York :Capricorn.

Flaubert, Gustave.(1950). Madame Bovary. Trans. Eleanor Marx Aveling. Intro. Carl Van Doren. New York: Random House.

Hassan, Ihab.(1982). The Dismemberment of Orpheus: Toward a Postmodern Literature.Wisconsin: University of Wisconsin Press.

Hooti, Noorbakhsh.(2011). Oscillation between Modernism to Postmodernism in Shakespeare's Hamlet. Theory and Practice in Language Studies. 327-336.

... (2011).Samuel Beckett's Waiting for Godot: A Postmodernist Study. English Language and Literature Studies ,Vol.1, No.1, 40-49.

Janovsky, Angela. Situation Irony in Literature: Definition and Examples.study.com/academy/lesson/situation-irony-in-literaturedefinition- examples.html

Kaplon,Megan(2012). Kate Chopin's The Awakening: Struggle Against Society and Nature. www.studentpulse.com/articles/657/katechopins-the-awakening-struggle-against-society-and-nature

Lewis, Barry.(2010).Postmodernism and Literature. In Stuart Sim(Ed.),The Routledge Companion to Postmodernism. New York: Routledge.

Lodge, David.(Ed.)(1992) . The Art of Fiction. London: Secker \&Workung.

Nicol, Bran.(2009). The Cambridge Introduction to Postmodern Fiction. Cambridge: CUP.

Norris, Christopher.(1982). Deconstruction: Theory and Practice. (Ed.)Terence Hawkes. London \& New York: Routledge.

Paris, Bernard J.(1997). Imagined Human Beings: A Psychological Approach to Character and Conflict in Literature. New York: New York UP.

Pease, Jane H. \& William H.(1993). Ladies, Women, \& Wenches: Choice and Constraint in Antebellum Charleston \& Boston. In Anne M. Boylan. Journal of Social History, 26,3, 646-648. (published by: Peter N. Stearns) http:// www.jstor.org/stable/3788640

Rosowski, Susan J.(1979). The Novel of Awakening. Genre, 13, 313-332.

Seyersted,Per.(1969). Kate Chopin : A Critical Biography. Oslo and Baton Rouge, 160-161,183.

Showalter, Elaine.(1988). Introduction. New Essays on The Awakening. Cambridge University Press.

... (2000).Tradition and the Female Talent: The Awakening as a Solitary Book. In Nancy A.Walker(Ed.), The Awakening : Case Studies in Contemporary Criticism(p/214). Boston: Bedford.

Skaggs, Peggy.(1974).Three Tragic Figures in Kate Chopin's The Awakening. Louisiana Studies: An Interdisciplinary Journal of the South, 4, 345-364.

Sprinkle, Russ(1998). The Awakening : A Critical Reception. sprinkle@glasscity.net

Thornton, Lawrence. (1980).The Awakening: A Political Romance. American Literature, 52,50-66.

Waugh, P.(1984). Metafiction: Theory and Practice of Self-Conscious Fiction. London \& New York: Methuen.

... (2006).An Aesthetic Value: Problems for Criticism. In The Theory and Practice of Literary Criticism: An Oxford Guide. Oxford: Oxford University Press.

Wilson ,Edmund(1966).Patriotic Gore. New York : O U Press.

Wyatt, Neil.(1995). Romanticism, Realism, Naturalism, and Local Color. The Literary Context of The Awakening in Kate Chopin Study Text. Created 1995, on the web: Available at: http:// www.vcu.edu/engweb/eng384/katemove.htm nwyatt@leo.vsla.edu

Zlotnick, Joan.(1968). A Woman's Will: Kate Chopin on Selfhood, Wifehood, and Motherhood. Markham Review, 3, no pagination. 